\title{
ANTIFUNGAL AND ANTIBACTERIAL ACTIVITIES OF JUICE AND ETHANOLIC EXTRACTS OF GARCINIA MANGOSTANA L. LEAVES
}

\section{DINIATIK ${ }^{1 *}$, ELZA SUNDHANI ${ }^{2}$, MUHAMMAD TAUFIQ NUGROHO ${ }^{1}$, EUIS NUR HIKMAH ${ }^{1}$, RETNO WAHYUNINGRUM ${ }^{1}$, SUPARMAN ${ }^{3}$}

\begin{abstract}
${ }^{1}$ Departement of Pharmaceutical Biology, Faculty of Pharmacy, Universitas Muhammadiyah Purwokerto, Jl. Raya Dukuhwaluh Purwokerto, Central Java 53182, Indonesia. ${ }^{2}$ Departement of Pharmacology and Clinical Pharmacy, Faculty of Pharmacy, Universitas Muhammadiyah Purwokerto, Jl. Raya Dukuhwaluh Purwokerto, Central Java 53182, Indonesia. ${ }^{3}$ Departement of Organic Chemistry, Faculty of Pharmacy, Universitas Muhammadiyah Purwokerto, Jl. Raya Dukuhwaluh Purwokerto, Central Java 53182, Indonesia.
\end{abstract} Email: diniatik@yahoo.com.au

Received: 23 September 2018, Revised and Accepted: 11 May 2019

ABSTRACT

Objective: Garcinia mangostana is a plant that can be used as a traditional medicine to treat various infectious diseases for the treatment of diarrhea, skin infection, and chronic wounds. The activity as antifungal and antibacterial of juice and ethanolic extract from $G$. mangostana leaves were investigated.

Methods: Juice and ethanolic extract were concentrated using a rotary evaporator to get concentrated extract with rendemen 2.571 and $5.647 \%$ $(\mathrm{w} / \mathrm{w})$. Juice and ethanolic extract dilution method were employed to evaluate the antifungal activity against Saccharomyces cerevisiae. Ethanolic extract dilution method was used to assess the antibacterial activity against Bacillus subtilis and Escherichia coli.

Results: The results of this research showed that juice and ethanolic extract were effective against $S$. cerevisiae, and the minimum inhibitory concentration was 1000 , and $500 \mathrm{mg} / \mathrm{mL}$. Antibacterial activity of the G. mangostana leaves ethanolic extract showed that the action was potential with the inhibition zone in B. subtilis and E. coli.

Conclusions: The conclusion of this study is that juice and ethanolic extract of $G$. mangostana leaves have possible antifungal and antibacterial activity.

Keywords: Garcinia mangostana, Antifungal, Antibacterial, Juice, Ethanolic extract.

(C) 2019 The Authors. Published by Innovare Academic Sciences Pvt Ltd. This is an open access article under the CC BY license (http://creativecommons. org/licenses/by/4. 0/) DOI: http://dx.doi.org/10.22159/ajpcr.2019.v12i7.29915

\section{INTRODUCTION}

Mangosteen (Garcinia mangostana) is one of the primary commodities of Indonesian export, known as the queen of tropical fruits. Even though the fruit has been exported, the availability of good quality fruit is still inadequate [1]. There were many reports of biological activity of $G$. mangostana. Several studies have shown that obtained xanthones from $G$. mangostana have remarkable biological activities such as antioxidant, antitumor, anti-inflammatory, antiallergy, antibacterial, antifungal, and antiviral activities [2,3]. The twig extract of $G$. mangostana was the most useful sample against platelet aggregation caused by arachidonic acid [4], and several studies had been designed to examine the anticancer activities, hepatocellular carcinoma human leukemia of xanthones from mangosteen fruit pericarp [5].

The concentration of secondary metabolites can differ between parts of the plant [6]. However, leaves are the most potent part of the plant to be used because they are not dependent on the season and interfere with the growth of the plant. The leaves of $G$. mangostana are proven to have high phenolic compounds and have the potential as antibacterial and antitumor activity [7]. Juice of leaves of G. mangostana was shown to have free radical scavenging activity against $\alpha, \alpha$-diphenyl$\beta$-picrylhydrazyl (DPPH) radicals with $\mathrm{IC}_{50} 19 \mathrm{ppm}$ [8]. The results of the previous research show the great potential as of $G$. mangostana. Mainly leaves, as compared with fruit and bark, leaves are not explored to prove antibacterial and antifungal activity. The use of leaves of $G$. mangostana as traditional medicine is by making juice.
The aims from this research are to compare the action of the extracted juice and ethanolic extract of leaves of $G$. mangostana as antifungal and antibacterial.

\section{MATERIALS AND METHODS}

Materials

Plant material

The leaf of $G$. mangostana (mangosteen) collection was carried out in Somagede Village, Somagede District, Banyumas Regency, Central Java, Indonesia, and identified in the Laboratory of Botany and Genetic Faculty of FKIP, Universitas Muhammadiyah Purwokerto, Indonesia.

\section{Antifungal and antibacterial assay}

Fungal and bacterial strains used were Saccharomyces cerevisiae and Bacillus subtilis FNCC 0059 then Escherichia coli ATCC 35218. The organism was obtained from of Microbiology laboratory, Universitas Muhammadiyah Purwokerto.

\section{Methods}

Preparation of juice

Fresh leaves of $G$. mangostana amount $3 \mathrm{~kg}$ were added water $3 \mathrm{l}$ at blander after bland was pressed with a flannel cloth and was concentrated using rotary evaporator and with water bath during 5 days with a temperature $<40^{\circ} \mathrm{C}$ to get concentrated extract produces. 


\section{Preparation ethanolic extract}

The leaves of G. mangostana were collected, dried, and pulverized using a mechanical grinder. $500 \mathrm{~g}$ of powder were extracted by maceration method with solvent water: ethanol 50\% (1:5) during $24 \mathrm{~h}$ and re-maceration with solvent water: ethanol $50 \%$ (1:4). After extract exhaustive extraction, ethanolic extract was collected and then concentrated under reduced pressure at $40^{\circ} \mathrm{C}$ using rotary evaporator.

\section{Antifungal assay}

\section{Identification of S. cerevisiae}

Identification of S. cerevisiae conducted on potato dextrose agar (PDA) at room temperature for $48 \mathrm{~h}$ to form colonies of soft cream colored, having a smell like yeast. Youth culture will form seed tubes "germ tube" when placed in serum for $3 \mathrm{~h}$ at temperature $37^{\circ} \mathrm{C}$.

\section{Preparation of medium}

$P D A$

A total of $19.5 \mathrm{~g}$ of PDA were weighed and $500 \mathrm{~mL}$ of distilled water heated on a hot plate, continually stirring until a homogeneous solution, and distilled water is added to replace the volume lost due to heating precisely $500 \mathrm{~mL}$. Further medium sterilized by autoclave at $121^{\circ} \mathrm{C}$ for 15 min (Aminiati, 2007).

\section{Potato dextrose broth (PDB)}

$12 \mathrm{~g}$ PDB were weighed and $500 \mathrm{~mL}$ of distilled water heated on a hot plate, continually stirring until a homogeneous solution, and distilled water is added to replace the volume lost due to heating precisely $500 \mathrm{~mL}$. Further medium sterilized by autoclave at $121^{\circ} \mathrm{C}$ for $15 \mathrm{~min}$.

\section{The culture of $S$. cerevisiae}

Cultures performed using methods that tilt and all the tools that are used have been sterilized using an autoclave. The yeast ose from 2 days streaking on PDA near a Bunsen flame then closed with sterile cotton and incubated for $48 \mathrm{~h}$ in an incubator with a temperature of $28^{\circ} \mathrm{C}$ for later use in antifungal tests. All processes are carried out in the laminar air flow, so to avoid contamination from the outside environment.

\section{Calculation of S. cerevisiae yeast}

One ose was of yeast $S$. cerevisiae 2 days old to be grown in a liquid medium of different PDB and then incubated for $48 \mathrm{~h}$ at $28^{\circ} \mathrm{C}$. After $48 \mathrm{~h}$, the number of colonies was calculated using the number of microbes indirectly, using successive dilution of the concentration of $10^{-5}-10^{-7}$ with distilled water. Then, take $1 \mathrm{~mL}$ of the solution was added $15 \mathrm{~mL}$ PDA together and inserted into each petri dish and let it harden, and then, incubated for $48 \mathrm{~h}$ at $28^{\circ} \mathrm{C}$. The number of fungal colonies in a petri dish should meet the test of the 30-300 colonies (Lay, 1994).

\section{Antifungal activity assay}

The test is done using some fungal inoculum colony assay is $30-300$ compliant. In a petri dish placed 7 paper disks that had been treated, as follows: One paper disk as negative control $(10 \%$ dimethyl sulfoxide [DMSO]), one paper disk with treatment (itraconazole), a paper disc with solvent control (distilled water), and four paper disks treatment with juice of mangosteen leaves each with concentration of $500 \mathrm{mg}$, $750 \mathrm{mg}, 1000 \mathrm{mg}$, and $1250 \mathrm{mg}$ do replication 3 times. The medium used is made by taking as many suspension $1 \mathrm{~mL}$ yeasts obtained dilution of test breeding and is poured into a petri dish. Then, the media were thawed and PDA was poured into a petri dish.
Furthermore, it was homogenized media culture with a shake form. Hardening media was used as data to obtain the antifungal test by calculating the inhibitory zone. Paper disks placed on agar medium, then each poured by the positive control, negative control, distilled water control, and each concentration using $10 \mathrm{~mL}$ micropipette. Then, incubated for $48 \mathrm{~h}$ at $28^{\circ} \mathrm{C}$. Inhibitory regions can be measured by looking at the diameter of the transparent area on each sample around the paper disk using calipers.

\section{Antibacterial assay \\ Preparation of medium \\ Nutrient agar (NA)}

$2.3 \mathrm{~g}$ of NA, put it in Erlenmeyer and dissolved with $1000 \mathrm{~mL}$ of distilled water, then heated to evaporate completely. Furthermore, the NA solution which was still warm was poured into a test tube $20 \mathrm{~mL}$ $10 \mathrm{ml}$ and $5 \mathrm{ml}$, respectively, then sterilized in an autoclave at $121^{\circ} \mathrm{C}$ for $15 \mathrm{~min}$.

Nutrient broth (NB)

$1.3 \mathrm{~g}$ of NB, put it in Erlenmeyer and dissolved with $100 \mathrm{~mL}$ of distilled water, heated until it disappeared completely. Then, the NB solution was poured into a test tube and sterilized in an autoclave at $121^{\circ} \mathrm{C}$ for $15 \mathrm{~min}$.

\section{The culture of B. subtilis and E. coli}

$5 \mathrm{~mL} \mathrm{NA}$ medium that is still liquid and put in a test tube and tilted let it solidify. B. subtilis and E. coli derived from stock were taken with a sterile ose needle and put into a test tube containing aseptically solid $\mathrm{NA}$ and incubated at $37^{\circ} \mathrm{C}$ for $24 \mathrm{~h}$. Growing isolates was carried out by isolating B. subtilis, and E. coli derived from stock taken with a sterile ose needle then suspended in a test tube containing NB aseptically, then incubated at $37^{\circ} \mathrm{C}$ for $24 \mathrm{~h}$.

\section{Antibacterial activity assay}

The test is done using some bacteria inoculums colony assay is $30-300$ compliant. 12 paper disc with a diameter of $2 \mathrm{~mm}$ prepares for six petri dish. In 12 disc paper dripped each concentration of juice and ethanolic extract of mangosteen leaves with a solvent with $10 \%$ DMSO, positive control was trickled with streptomycin $1 \mu \mathrm{g} / \mu \mathrm{l}$. Then, in each petri dish which contained $20 \mathrm{~mL} \mathrm{NA}$ media and a suspension of B. subtilis and E. coli as much as $1 \mathrm{~mL}$ placed sequentially six paper discs which had been penetrated by different concentrations of ethanolic extract and juice of mangosteen leaves. There also put paper discs for negative control, positive control, and solvent control. Then, placed in an incubator at $37^{\circ} \mathrm{C}$ for $24 \mathrm{~h}$. The diameter of the inhibitory zone is observed.

\section{RESULTS AND DISCUSSION}

This study was designed to assess the antifungal activities from juice and ethanolic extract and also to determine the antibacterial activities of ethanolic extract of G. mangostana. Extract the juice of leaves of G. mangostana we get by way of blending fresh leaves of $G$. mangostana after pressed; the filtrate was concentrated used rotary evaporator to get the concentrated extract. The ethanolic extract obtained from fresh which dried in the sun covered with black cloth, then was bland with a blender to minimize the surface area so that the contact surface of the particles with ethanol as solvent bigger bulbs and extraction more optimal. The method to extraction was used is maceration, by soaking the powder in the liquid botanicals solvent, is done stirring and remaceration to improve the effectiveness of the extraction, macerated

Table 1: Rendement juice and extract G. mangostana leaves

\begin{tabular}{|c|c|c|c|c|c|}
\hline \multicolumn{3}{|l|}{ Juice } & \multicolumn{3}{|l|}{ Ethanolic extract } \\
\hline Fresh leaves (g) & Thick extract (g) & Rendement $(\% \mathrm{w} / \mathrm{w})$ & Simplisia (g) & Thick extract (g) & Rendement $(\% \mathrm{w} / \mathrm{w})$ \\
\hline 3000 & 77.14 & 2.571 & 500 (from $2 \mathrm{~kg}$ leaves) & $116,94 \mathrm{~g}$ & $5,647 \%$ \\
\hline
\end{tabular}

G. mangostana: Garcinia mangostana 
for $24 \mathrm{~h}$ with a comparison between simplicia. Extracts derived either from the juice or extract were evaporated with a rotary evaporator and over a water bath until thick consistency. Fading of the extract was done to eliminate solvent solution so as not to affect the antifungal, antibacterial activities assay.

Leaves from G. mangostana was bland and then concentrated and got thick extract $77.14 \mathrm{~g}$ and ethanolic extract obtains $116,94 \mathrm{~g}$ with rendemen 2.571 and $5,647 \%(\mathrm{w} / \mathrm{w})$ shown in Table 1 . The results of an organoleptic extract of juice and the ethanolic extract are scent typical, bitter taste, and the color is brown.

The calculation of the number of colony $S$. cerevisiae using the total plate count in Table 2 showed that fungal cultures are a qualified suspension in dilution $10^{-6}$. The results of the test antifungal activity

Table 2: Calculation of the number of colonies $S$. cerevisiae

\begin{tabular}{lll}
\hline Dilutions & \multicolumn{2}{l}{ The number of colonies in a petri dish } \\
\cline { 2 - 3 } & $\mathbf{1}$ & $\mathbf{2}$ \\
\hline $10^{-5}$ & 310 & 325 \\
$10^{-6}$ & 110 & 90 \\
$10^{-7}$ & 10 & 22 \\
\hline
\end{tabular}

S. cerevisiae: Saccharomyces cerevisiae

Table 3: Antifungal activity from juice and ethanolic extract

\begin{tabular}{lllll}
\hline \multirow{2}{*}{ Concentration (mg/ml) } & \multicolumn{5}{c}{ Zone of inhibition (cm) } & Average \pm SD \\
\cline { 2 - 4 } & I & II & III & \\
\hline Juice & & & & \\
500 & 1.855 & 1.635 & 1.745 & $1.745 \pm 0.110$ \\
750 & 2.210 & 1.935 & 1.895 & $2.013 \pm 0.171$ \\
1000 & 2.145 & 2.095 & 2.080 & $2.107 \pm 0.034$ \\
1250 & 2.145 & 2.310 & 2.025 & $2.160 \pm 0.143$ \\
Positive control & 1.370 & 1.025 & 1.790 & $1.395 \pm 0.383$ \\
Ethanolic & Extract & & & \\
500 & - & - & - & - \\
750 & - & - & - & - \\
1000 & 0.970 & 0.955 & 1.10 & $1.008 \pm 0.079$ \\
1250 & 1.00 & 1.11 & 1.115 & $1.075 \pm 0.065$ \\
Positive control & 1.025 & 1.52 & 1.09 & $1.212 \pm 0.269$ \\
\hline
\end{tabular}

Table 4: Antibacterial activity ethanolic extract against B. subtilis

\begin{tabular}{lllll}
\hline Concentration (mg/ml) & \multicolumn{2}{l}{$\begin{array}{l}\text { Zone of } \\
\text { inhibition (cm) }\end{array}$} & Average \pm SD \\
\cline { 2 - 4 } & I & II & III & \\
\hline 250 & 11.15 & 11.27 & 12.40 & $11.607 \pm 0.690$ \\
500 & 16.30 & 16.25 & 15.00 & $15.850 \pm 0.737$ \\
750 & 19.20 & 19.10 & 19.25 & $19.183 \pm 0.076$ \\
Positive control & 23.35 & 24.50 & 24.45 & $24.100 \pm 0.650$ \\
\hline
\end{tabular}

SD: Standard deviation, B. subtilis: Bacillus subtilis

Table 5: Antibacterial activity ethanolic extract against $E$. coli

\begin{tabular}{lllll}
\hline Concentration $(\mathbf{m g} / \mathbf{m l})$ & \multicolumn{2}{l}{$\begin{array}{l}\text { Zone of } \\
\text { inhibition (cm) }\end{array}$} & Average \pm SD \\
\cline { 2 - 4 } & I & II & III & \\
\hline 250 & 12.05 & 11.05 & 11.30 & $11.467 \pm 0.520$ \\
500 & 17.05 & 18.07 & 16.10 & $17.073 \pm 0.985$ \\
750 & 20.15 & 21.00 & 20.50 & $20.550 \pm 0.427$ \\
Positive control & 23.35 & 12.40 & 18.00 & $17.917 \pm 5.475$ \\
\hline SD: Standard deviation, E. coli: Escherichia coli & & &
\end{tabular}

SD: Standard deviation, E. coli: Escherichia col juice and ethanol extracts in Table 3 showed that ethanolic extract had the greater inhibitory power of the G. mangostana leaves with minimum inhibition concentration (MIC) 500 and $1000 \mathrm{mg} / \mathrm{mL}$.

Tables 4 and 5 show that in the ethanolic extract of mangosteen leaves had antibacterial activity against the $B$. subtilis as Gram-positive bacteria and $E$. coli bacteria as Gram-negative bacteria in each extract concentration and positive control of Streptomycin $1 \mu \mathrm{g} / \mu \mathrm{l}$ gave the zone of inhibition. The DMSO solvent control as suspending agent of extract and $70 \%$ ethanol solvent control did not have antibacterial activity because it could not produce clear around the disc paper. Geetha et al. [7] reported that antibacterial activity from aqueous and ethanolic extract of $G$. mangostana fruit rinds was potential with the inhibition zone in E. coli, Shigella dysenteriae, Vibrio cholerae, Salmonella typhi, Klebsiella pneumonia, Pseudomonas aeruginosa, and Staphylococcus aureus.

G. mangostana leaves contain polyphenolic major role in the prevention of various diseases [8]. Juice of $G$. mangostana contains polyphenolic compound such as flavonoid and tannin [9]. G. mangostana leaves have more potential activity than peel, bark, and essential oils for against DPPH as radical [10]. G. mangostana also contains $\alpha$-mangostin compounds which are proven to have potential antifungal and antibacterial activity [11]. Xanthone is the major compound of G. mangostana showed high-antifungal activity (against Candida albicans and Aspergillus niger) and antibacterial activity (against B. subtilis, E. coli, S. aureus, and P. aeruginosa) [12].

Juice and ethanolic extract of G. mangostana leaves have the effect of inhibiting the growth of fungi cause food spoilage as $S$. cerevisiae FNCC 3012. Mechanisms of antimicrobial compounds in inhibiting the growth of mold in some way damage the structure of the cell wall by inhibiting the formation or cause lysis of the cell wall are formed. Changing the permeability of the cytoplasmic membrane which will cause inhibit growth or death cells (denaturation of proteins), as well as inhibiting the enzyme in resulting in disruption of cell metabolism or cell death.

Antibacterial activity of ethanolic extract G. mangostana on B. subtilis is bactericidal while $E$. coli is bacteriostatic. This difference is likely to occur due to differences in cell wall composition in B. subtilis as Grampositive bacteria and E. coli as Gram-negative bacteria. Single-layered Gram positive bacterial cell wall with 1-4\% lipid content. Three-layered cell wall Gram negative bacteria consisting of lipoproteins. Outer membrane contain phospholipids and lipopolysaccharides, with lipid content in cell walls ranging from 11 to $22 \%$. The outer phospholipid membrane causes antibacterial chemical components that are difficult to penetrate the cell wall of Gram-negative bacteria.

\section{CONCLUSIONS}

Antifungal activities of juice and ethanolic extract of $G$. mangostana leaves were 1000 and $500 \mathrm{mg} / \mathrm{ml}$ in MIC against $S$. cerevisiae. Antibacterial activity from the ethanolic extract of $G$. mangostana leaves was potential with the inhibition zone in B. subtilis and E. coli. Needs further confirmation of chemical compounds that are containing in juice of mangosteen leaves.

\section{ACKNOWLEDGMENT}

We would like to thank the Ministry of Research, Technology, and the Higher Education Republic of Indonesia for the research funding.

\section{DECLARATION OF CONFLICT OF INTEREST}

The authors declared that they had no conflicts of interest with respect to their authorship or the publication of this article.

\section{REFERENCES}

1. Tjitrosemito S, Poerwanto R, Juliarni J. Secretory duct structure and phytochemistry compounds of yellow latex in mangosteen fruit. 
HAYATI J Biosci 2008;15:99-104

2. Priya VV, Mallika J, Mohan SK, Saraswathi P, Gopan SV. Antimicrobial activity of pericarp extract of G. mangostana Linn. Int J Pharma Sci Res 2010;1:278-1.

3. Gutierrez-Orozco F, Failla ML. Biological activities and bioavailability of mangosteen xanthones: A critical review of the current evidence. Nutrients 2013;5:3163-83

4. Jantan I, Jumuddin FA, Saputri FC, Rahman K. Inhibitory effects of the extracts of Garcinia species on human low-density lipoprotein peroxidation and platelet aggregation in relation to their total phenolic contents. J Med Plants Res 2011;5:2699-709.

5. Pedraza-Chaverri J, Cárdenas-Rodríguez N, Orozco-Ibarra M, PérezRojas JM. Medicinal properties of mangosteen (Garcinia mangostana). Food Chem Toxicol 2008;46:3227-39.

6. Achakzai AK, Achakzai P, Masood A, Kayani SA, Tareen RB. Response of plant parts and age on the distribution of secondary metabolites on plants found in quetta. Pak J Bot 2009;41:2129-35

7. Geetha RV, Roy A, Lakshmi T. Evaluation of anti bacterial activity of fruit rind extract of Garcinia mangostana Linn on enteric pathogens-an in vitro study. Asian J Pharma Clini Res 2011;4:115-8.

8. Cunha BL, Fance JP, Moraes AA, Chaves AL, Gaiba S, Fontana R, et al. Evaluation of antimicrobial and antitumoral activity of G. mangostana. (mangosteen) grown in Southeast Brazil. Acta Cir Bras 2014;29:21-8.

9. Izzati NN, Diniatik D, Rahayu WS. Aktivitas antioksidan ekstrak perasan daun manggis (G. mangostana.) berdasarkan metode DPPH (2.2 Diphenyl-1-phycryl hydrazil). Pharmacy 2012;9:111-21.

10. Palakawong CE. Antioxidant and antimicrobial activities of crude extracts from mangosteen (G. mangostana.) parts and some essential oils. Int Food Res J 2010;17:583-9.

11. Ibrahim MY Hashim NM, Mariod AA, Mohan S, Abdulla MA, et al. $\alpha$-Mangostin from G. mangostana Inn: An updated review of its pharmacological properties. Arab J Chem 2016;9:317-29.

12. Narasimhan S, Maheshwaran S, Abu-yousef IA, Majdalawieh AF, Rethavathi J, Das PE, et al. Anti-bacterial and anti-fungal activity of xanthones obtained via semi-synthetic modification of $\alpha$-mangostin from Garcinia mangostana. Molecules 2017;22:E275. 